\title{
Pengaruh Tayangan Drama Korea Itaewon Class Terhadap Motivasi Menjadi Entrepreneurship
}

\author{
Salma Putri Hadiyani ${ }^{1 *}$, Zainal Abidin², \& Wahyu Utamidewi ${ }^{3}$ \\ 1,2,3 Universitas Singaperbangsa Karawang, Indonesia \\ *email: salmaputri24.sp@gmail.com
}

\begin{abstract}
This study aims to determine the effect of the message content of Korean dramas and the influence of the characteristics of the role of Park Saeroyi who works hard in opening a business and doing business in the Korean drama series "Itaewon Class" on motivational behavior to become entrepreneurship. The researcher uses the uses and effect theory with variables adjusted to the "Itaewon Class" show, which is classified into indicators of Intensity, Message Content, and Attractiveness. The analysis technique used in this study is an explanatory analysis technique with classical assumptions and simple regression analysis, which is a form of research based on data collected during systematic research from the object under study by combining the relationships between the variables involved using a questionnaire as the main instrument for collecting data, with a total of 66 respondents. The results of this study indicate that respondents get positive results or effects from the media, namely "Itaewon Class" in all indicators with the dominant indicator being Message Content and Attractiveness, and unexpected effects occur in the Intensity indicator. The results are generally stated that respondents get the influence of the Korean drama "Itaewon Class" and have the motivation to become entrepreneurship.
\end{abstract}

\section{Keywords: Itaewon Class Korean Drama, Motivation and Entrepreneurship}

\begin{abstract}
Abstrak: Penelitian ini bertujuan untuk mengetahui pengaruh isi pesan drama Korea dan pengaruh karakteristik peran Park Saeroyi yang kerja keras dalam membuka usaha dan berbisnis pada serial drama Korea "Itaewon Class" terhadap perilaku motivasi menjadi entrepreneurship. Peneliti menggunakan teori uses and effect dengan variabel disesuaikan dengan tayangan "Itaewon Class" yaitu digolongkan menjadi indikator Intensitas, Isi Pesan, dan Daya Tarik. Teknik analisis yang digunakan dalam penelitian ini adalah teknik analisis eksplanatori dengan asumsi klasik dan analisis regresi sederhana yaitu suatu bentuk penelitian berdasarkan data yang dikumpulkan selama penelitian secara sistematis dari objek yang diteliti dengan menggabungkan hubungan antar variabel yang terlibat didalamnya menggunakan kuesioner sebagai instrumen utama untuk mengumpulkan data, dengan jumlah 66 responden. Hasil penelitian ini menunjukkan bahwa responden mendapatkan hasil atau efek yang positif dari media yaitu tayangan "Itaewon Class" dalam semua indikator dengan indikator yang dominan adalah Isi Pesan dan Daya Tarik, dan terjadi efek yang tidak diharapkan sebelumnya di indikator Intensitas. Hasil secara umum menyatakan bahwa responden mendapatkan pengaruh dari tayangan drama Korea "Itaewon Class" dan memiliki motivasi menjadi entrepreneurship.
\end{abstract}

Kata Kunci: Tayangan Drama Korea Itaewon Class, Motivasi, dan Entrepreneurship

Copyright (c) 2021 The Authors. This is an open access article under the CC BY-SA 4.0 license (https://creativecommons.org/licenses/by-sa/4.0/)

\section{PENDAHULUAN}

Media massa merupakan sarana untuk memenuhi kebutuhan manusia akan informasi dan hiburan. Media dapat menggerakkan emosi atau mempengaruhi perasaan, tantangan, dan mendefinisikan masyarakat serta membentuk realitas khalayak. Nurudin (2013) memberikan beberapa asumsi dasar tentang peran atau fungsi media di tengah kehidupan masyarakat saat ini, antara lain; Media adalah 
sebuah industri, media terus berkembang seiring dengan perkembangan teknologi dan menciptakan lapangan kerja, barang, dan jasa. Media juga merupakan wadah informasi untuk menampilkan peristiwa-peristiwa dalam kehidupan. Salah satu media adalah internet. Melalui internet, masyarakat dapat menonton film, mendengar radio, mengakses media sosial dan lain sebagainya.

Menurut Storey (2010) budaya adalah jenis perkembangan intelektual spiritual, estetika, perspektif kehidupan tertentu dari masyarakat, periode, atau kelompok tertentu. Istilah "budaya populer" sendiri dalam bahasa latin merujuk secara harfiah pada "culture of the people" (budaya orang - orang atau masyarakat). Melalui kebudayaan yang tersebar semua orang bisa berpikir seragam dengan mengikuti budaya tersebut seperti budaya berpakaian yang selalu berubah dan tampilan secara unik di berbagai tempat dan waktu, berbagai makanan dari yang tradisional hingga kreasi makanan instan, juga cita - cita atau profesi yang diinginkan bisa termotivasi melalui sebuah film atau drama.

Korea Selatan adalah contoh ekspansi budaya populer melalui bentuk hiburan. Proses penyebaran budaya Korea ke seluruh dunia disebut dengan Hallyu atau Korean Wave, yang merupakan sebutan untuk tersebarnya budaya populer Korea secara global di berbagai negara. Menurut Okirianti (2011) hallyu mendorong masyarakat penerima untuk belajar bahasa Korea dan kebudayaan Korea. Hal ini terbukti dengan banyaknya penggemar mulai dari penggemar Korean drama dan Korean music.

Menurut Dhani (2017) bahwa sebanyak 80,61 persen masyarakat menyatakan drama korea meliliki alur cerita yang menarik, mempunyai isi pesan yang memiliki unsure kedekatan dengan kehidupan asli masyarakat, dan cerita yang tidakbertele-tele adalah alasan utama mereka menonton drama Korea. Penelitian terdahulu mengenai Pengaruh Drama Korea pernah dilakukan oleh Fitri (2019) yang berjudul Pengaruh Drama Korea terhadap Karakter Mahasiswa PAI Universitas Islam Negeri Raden Intan Lampung dengan hasil bahwa mahasiswa menyukai Drama Korea sebanyak 60\% sehingga responden yang menyukai Drama Korea mempengaruhi karakter nya dalam kehidupan sehari-hari seperti menunda waktu shalat, lalai membaca Al-Qur'an, terlambat datang ke kampus dan lain sebagainya. 
Salah satu drama Korea yang berjudul "Itaewon Class" telah menjadi fenomena di tahun 2020 karena berhasil meraih rating tertinggi. Menurut data dari Nielsen Korea, rating rata-rata nasional episode terakhir drama Korea Itaewon Class adalah sebesar 16,5 persen dan rating rata-rata daerah perkotaan Seoul adalah $18,3 \%$. Secara garis besar, drama ini menceritakan tentang kisah sekelompok anak muda yang keras kepala dan pemberani yang berusaha bangkit dari dunia yang mereka anggap tidak adil. Dunia tersebut adalah sebuah lingkungan daerah Itaewon, Seoul, tempat mereka membuka bisnis makanan.

Menurut Siregar (2019), motivasi merupakan suatu dorongan yang menyebabkan seseorang untuk bertindak atau berperilaku dengan secara motivasional, yakni perilaku yang mengacu pada munculnya faktor yang mendorong sesorang untuk melakukan atau tidak melakukan sesuatu. Motivasi dapat dikatakan sebagai daya penggerak dari dalam diri subjek untuk melakukan kegiatan tertentu guna mencapai tujuan. Menurut Shaleh (2004) beberapa fungsi motivasi adalah untuk mendorong perilaku atau tindakan. Motivasi berperan sebagai pemandu, artinya membimbing tindakan untuk mencapai tujuan yang diharapkan. Motivasi juga berperan sebagai penggerak, artinya motivasi akan berfungsi sebagai penentu kecepatan suatu pekerjaan, dan motivasi adalah penolong yang harus dilakukan untuk mencapai tujuan.

Menurut Sunyoto (2013) entrepreneurship adalah sikap untuk menciptakan hal-hal baru serta bernilai bagi diri sendiri dan orang lain. Menurut definisi ini, entrepreneurship tidak hanya untuk kepentingan pribadi, tetapi juga harus memiliki nilai sosial. Dalam dunia entrepreneurship, peluang merupakan kesempatan untuk mewujudkan atau menjalankan suatu usaha dengan tetap memperhitungkan resiko yang dihadapi. Seorang entrepreneur memiliki beberapa ciri, yaitu disiplin usaha untuk mengatur atau mengontrol perilaku seseorang untuk mencapai suatu tujuan, sikap mandiri untuk tidak bergantung pada keputusan akan apa yang harus dilakukan dengan orang lain, sikap realistis terhadap cara berpikir yang sesuai dengan kenyataan, kejujuran dan komitmen tinggi mengarahkan fokus pikiran pada tugas dan usahanya.

Menurut Rahmawati (2014), penggunaan teori uses and effect dapat dilihat pada media massa yang memegang peran penting perkembangan suatu gejala 
sosial. Teori uses and effect, merupakan teori yang berhubungan antara pengguna, media, audience, dan efek (hasilnya). Menurut Bungin (2006) teori ini adalah pengetahuan mengenai penggunaan media dan penyebabnya. Contoh dari teori uses and effect bias dilihat dari kebiasaan seseorang dalam menonton atau mendengarkan media massa, seperti kebiasaan orang menonton drama korea yang menimbulkan sebuah effect dari apa yang dilihat.

Berdasarkan uraian yang telah dipaparkan peneliti tertarik untuk mengetahui maksud dari penelitian ini adalah untuk mengetahui "Seberapa Besar Pengaruh Tayangan Drama Korea Itaewon Class terhadap Motivasi untuk menjadi Entrepreneurship?".

\section{METODE PENELITIAN}

Penelitian ini menggunakan metode survei eksplanatori (explanatory survey). Menurut Darmawan (2013) menyatakan bahwa survei bersifat eksplanatori yaitu penelitian yang harus dilakukan penjelasan atau hubungan, pengaruh, atau adanya hubungan sebab akibat. variabel yang diuji hubungan kausalitasnya dalam penelitian ini adalah variabel tayangan drama Korea "Itaewon Class" (X) yang terdiri dari intensitas, isi pesan dan daya atrik. Sedangkan motivasi menjadi entrepreneurship (Y) yang terdiri dari perubahan, perasaan, reaksi.

Pengumpulan data dilakukan melalui metodei survei terhadap populasi penelitian dengan menggunakan intrumen kuesioner. Kuesioner disusun secara online sehingga responden tinggal memilih jawaban sesuai dengan pilihan yang disediakan. Untuk menentukan ukuran sampel peneliti menggunakan rumus Taro Yamane, yaitu;

$$
n=\frac{N}{N \cdot d^{2}+1}
$$

Teknik analisis data dalam peneltian ini yaitu; Uji Normalitas, Uji Regresi Sederhana, Uji Parsial T, dan koefisien Determinasi

\section{HASIL DAN PEMBAHASAN}

Menurut (Sugiyono, 2010) uji validitas adalah derajat penentuan antara data yang terjadi pada objek penelitian dengan kekuatan yang dapat dilaporkan oleh penelitian. Jadi, data yang valid adalah data yang tidak berbeda antara data yang 
dilaporkan oleh peneliti dengan data yang sebenarnya terjadi pada objek penelitian. Validitas dimaksudkan untuk menyatakan sejauh mana suatu instrument (misalnya kuesioner) akan menukur apa yang ingin diukur. Perhitungan pada uji validitas ini menggunakan korelasi pearson product moment dengan kriteria yang harus dipenuhi untuk menilai validitas isntrumen tersebut adalah:

a. Jika $r$ hitung $>r$ tabel, maka butir-butir pernyataan dari kuesioner adalah valid

b. Jika $r$ hitung < r tabel, maka butir - butir pernyataan dari kuesioner adalah tidak valid.

Tabel 1 Hasil Uji Validitas (X)

\begin{tabular}{ccccc}
\hline \multirow{2}{*}{ Variabel } & Item & r tabel & r hitung & \multirow{2}{*}{ Ket } \\
\hline \multirow{3}{*}{ Intensitas } & 1 & 0,497 & 0,741 & VALID \\
\cline { 2 - 5 } & 2 & 0,497 & 0,741 & VALID \\
\cline { 2 - 5 } & 3 & 0,497 & 0,905 & VALID \\
\cline { 2 - 5 } & 4 & 0,497 & 0,922 & VALID \\
\hline \multirow{3}{*}{ Isi Pesan } & 5 & 0,497 & 0,666 & VALID \\
\cline { 2 - 5 } & 6 & 0,497 & 0,918 & VALID \\
\cline { 2 - 5 } & 7 & 0,497 & 0,936 & VALID \\
\cline { 2 - 5 } & 8 & 0,497 & 0,702 & VALID \\
\hline \multirow{3}{*}{ Daya tarik } & 10 & 0,497 & 0,586 & VALID \\
\cline { 2 - 5 } & 11 & 0,497 & 0,789 & VALID \\
\cline { 2 - 5 } & 12 & 0,497 & 0,758 & VALID \\
\hline
\end{tabular}

Sumber: Hasil Penelitian 2021

Banyaknya data adalah $n=14$ dan taraf signifikan $n=5 \%$ berdasarkan pada tabel diatas diketahui nilai $\mathrm{r}$ tabel sebesar 0,497. Kemudian dapat dilihat pada tabel diatas, seluruh pernyataan dinyatakan valid karena nilai $r$ hitung lebih besar daripada nilai $r$ tabel

Tabel 2 Hasil Uji Validitas (Y)

\begin{tabular}{ccccc}
\hline \multirow{2}{*}{ Variabel } & Item & r tabel & r hitung & Ket \\
\hline \multirow{2}{*}{ Perubahan } & 14 & 0,497 & 0,628 & VALID \\
\cline { 2 - 5 } & 15 & 0,497 & 0,784 & VALID \\
\cline { 2 - 5 } & 16 & 0,497 & 0,862 & VALID \\
\hline \multirow{2}{*}{ Perasaan } & 17 & 0,497 & 0,894 & VALID \\
\cline { 2 - 5 } & 18 & 0,497 & 0,710 & VALID \\
\hline \multirow{2}{*}{ Reaksi } & 19 & 0,497 & 0,700 & VALID \\
\cline { 2 - 5 } & 20 & 0,497 & 0,693 & VALID \\
\hline
\end{tabular}


Banyaknya data adalah $n=14$ dan taraf signifikan $n=5 \%$ berdasarkan pada tabel diatas diketahui nilai $r$ tabel sebesar 0,497. Kemudian dapat dilihat pada tabel diatas, seluruh pernyataan dinyatakan valid karena nilai $\mathrm{r}$ hitung lebih besar daripada nilai $r$ tabel

Menurut Arikunto (2010) reliabilitas merupakan instrument yang cukup dipercaya untuk digunakan sebagai alat pengumpul data karena intrumen tersebut sudah baik. Pengukuran reliabilitas dalam penelitian ini dengan menggunakan Teknik varians Alpha Cronbach yang dibantu dengan program SPSS, dengan dasar pengambilan keputusan sebagai berikut:

a. Jika nilai Cronbach's Alpha > dari 0,60 maka kuesioner dinyatakan reliabel atau konsisten.

b. Jika nilai Cronbach's Alpha < dari 0,60 maka kuesioner dinyatakan tidak reliabel atau tidak konsisten.

Tabel 3 Hasil Uji Reliabilitas

\begin{tabular}{lcc}
\hline \multicolumn{1}{c}{ Variabel } & $\begin{array}{c}\text { Cronbach's } \\
\text { Alpha }\end{array}$ & N of items \\
\hline Intensitas & 0,854 & 5 \\
\hline Isi Pesan & 0,848 & 5 \\
\hline Daya Tarik & 0,425 & 3 \\
\hline Perubahan & 0,627 & 3 \\
\hline Perasaan & 0,448 & 2 \\
\hline Reaksi & 0,268 & 2 \\
\hline
\end{tabular}

Sumber: Hasil Penelitian, 2021

Berdasarkan data tabel diatas diketahui nilai Cronbach's Alpha seluruh variabel >0,60 maka seluruh instumen kuesioner dinyatakan konsisten atau reliabel.

Analisis data melakukan kegiatan pengelompokkan data berdasarkan variabel dan jenis responden, membuat tabulasi data berdasarkan variabel dari seluruh responden, dan melakikan perhitungan untuk menguji hipotesis yang telah diajukan.

Tabel 4 Tanggapan Intensitas

\begin{tabular}{llllll}
\hline & SS & S & RR & TS & STS \\
\hline Item 1 & 3 & 6 & 6 & 30 & 21 \\
\hline Item 2 & 8 & 9 & 3 & 31 & 15 \\
\hline Item 3 & 36 & 22 & 1 & 4 & 3 \\
\hline Item 4 & 13 & 24 & 12 & 14 & 3 \\
\hline
\end{tabular}




\begin{tabular}{|c|c|c|c|c|}
\hline Item 5 & 31 & 10 & 10 & \\
\hline
\end{tabular}

Berdasarkan tabel diatas diketahui mayoritas responden menjawab setuju atas kelima item pernyataan mengenai intensitas menonton tayangan drama korea Itaewon Class. Hal ini menunjukkan penggunaan media mendapatkan stimulus serta rangsangan untun menonton drama korea Itaewon Class.

Tabel 5 Tanggapan Isi Pesan

\begin{tabular}{llllll}
\hline & SS & S & RR & TS & STS \\
\hline Item 6 & 28 & 31 & 5 & 2 & 0 \\
\hline Item 7 & 33 & 32 & 1 & 0 & 0 \\
\hline Item 8 & 17 & 40 & 9 & 0 & 0 \\
\hline Item 9 & 38 & 28 & 0 & 0 & 0 \\
\hline Item 10 & 28 & 28 & 8 & 1 & 1 \\
\hline
\end{tabular}

Sumber: Hasil Olahan Data Peneliti, 2021

Berdasarkan tabel diatas diketahui mayoritas responden menjawab setuju atas kelima item pernyataan mengenai isi pesan tayangan drama korea Itaewon Class. Hal ini berarti isi pesan drama korea Itaewon Class mengenai kerja keras dalam berbisnis seorang remaja memberikan efek positif bagi responden.

\begin{tabular}{llllll}
\multicolumn{7}{c}{ Tabel 6 Tanggapan Daya Tarik } \\
\hline & SS & S & RR & TS & STS \\
\hline Item 11 & 18 & 24 & 7 & 15 & 2 \\
\hline Item 12 & 9 & 27 & 14 & 14 & 2 \\
\hline Item 13 & 16 & 33 & 13 & 4 & 0 \\
\hline
\end{tabular}

Sumber: Hasil Olahan Data Peneliti, 2021

Berdasarkan tabel diatas diketahui mayoritas responden menjawab setuju atas 3 item. Hal ini berarti penggunaan media tayangan drama korea Itaewon Class responden tertarik karena pemeran utama yang terkenal dan sinematograi negara Korea yang indah.

Tabel 7 Tanggapan Perubahan

\begin{tabular}{llllll}
\hline & SS & S & RR & TS & STS \\
\hline Item 14 & 15 & 28 & 19 & 3 & 1 \\
\hline Item 15 & 13 & 28 & 17 & 7 & 1 \\
\hline Item 16 & 13 & 27 & 19 & 6 & 1 \\
\hline
\end{tabular}

Sumber: Hasil Data Olahan Peneliti, 2021 
Berdasarkan tabel diatas diketahui mayoritas responden menjawab setuju atas ketiga item pernyataan mengenai perubahan motivasi menjadi entrepreneurship. Hal ini berarti responden setelah menonton tayangan drama korea Itaewon Class memiliki ketertarikan dalam bidang entrepreneurship dan mempelajari strategi berbisni untuk membuka usaha.

\section{Tabel 8 Tanggapan Perasaan}

\begin{tabular}{llllll}
\hline & SS & S & RR & TS & STS \\
\hline Item 17 & 14 & 32 & 16 & 3 & 1 \\
\hline Item 18 & 7 & 27 & 28 & 3 & 1 \\
\hline
\end{tabular}

Sumber: Hasil Data Olahan Peneliti, 2021

Berdasarkan tabel diatas diketahui mayoritas responden menjawab setuju atas kedua item pernyataan mengenai perasaan motivasi menjadi entrepreneurship. Hal ini berarti responden menonton tayangan drama korea Itaewon Class memiliki motivasi untuk menjadi entrepreneur dan ingin menjadi seseorang yang bekerja keras dalam keinginannya membuka usaha seperti pada karakter di drama korea Itaewon Class

Tabel 9 Tanggapan Reaksi

\begin{tabular}{llllll}
\hline & SS & S & RR & TS & STS \\
\hline Item 19 & 18 & 36 & 11 & 1 & 0 \\
\hline Item 20 & 6 & 20 & 22 & 14 & 4 \\
\hline
\end{tabular}

Sumber: Hasil Data Olahan Peneliti, 2021

Berdasarkan tabel diatas diketahui mayoritas responden menjawab setuju atas kedua item pernyataan mengenai reaksi motivasi menjadi entrepreneurship. Hal ini berarti responden setelah menonton tayangan drama korea Itaewon Class akhirnya membuka sebuah usaha karena termotivasi dari tayangan tersebut. 
Tabel 10 Uji Normalitas

\begin{tabular}{llr}
\hline \multicolumn{3}{c}{ One-Sample Kolmogorov-Smirnov Test } \\
\hline & & $\begin{array}{r}\text { Unstandardiz } \\
\text { ed Residual }\end{array}$ \\
\hline $\mathrm{N}$ & & 66 \\
\hline Normal Parameters $^{\mathrm{a}, \mathrm{b}}$ & Mean & .0000000 \\
\cline { 2 - 3 } & $\begin{array}{l}\text { Std. } \\
\text { Deviation }\end{array}$ & 4.48896727 \\
\hline Most Extreme & Absolute & .066 \\
\cline { 2 - 3 } Differences & Positive & .050 \\
\cline { 2 - 3 } & Negative & -.066 \\
\hline Test Statistic & & .066 \\
\hline Asymp. Sig. (2-tailed) & & $.200^{\mathrm{c}, \mathrm{d}}$ \\
\hline
\end{tabular}

Dari hasil uji normalitas menyatakan nilai Asymp Sign (2-tailed) sebesar $0,200>0,05$. Berdasarkan hasil tersebut dapat dinyatakan data yang digunakan dalam penelitian ini telah berdistribusi normal.

Tabel 11 Uji Regresi Sederhana

\begin{tabular}{cccccc}
\hline \multicolumn{7}{c}{ Coefficients $^{\mathbf{a}}$} \\
\hline \multirow{2}{*}{ Model } & $\begin{array}{c}\text { Unstandardized } \\
\text { Coefficients }\end{array}$ & $\begin{array}{c}\text { Standardized } \\
\text { Coefficients }\end{array}$ & \multirow{2}{*}{$\mathrm{t}$} & \multirow{2}{*}{ Sig. } \\
\cline { 2 - 5 } & $\mathrm{B}$ & Std. Error & Beta & & \\
\hline $\begin{array}{c}\text { (Constant) } \\
\text { Tayangan Itaewon } \\
\text { Class }\end{array}$ & 6.962 & 5.231 & & 1.331 & .188 \\
\hline
\end{tabular}

Penelitian ini dilakukan untuk menguji seberapa besar pengaruh tayangan drama Korea Itaewon Class terhadap motivasi menjadi entrepreneurship. Berdasarkan hasil tabel diatas maka didapatkan uji regresi sederhana dari tabel Coefficients diperoleh nilai signifikansi sebesar 0,001 $<0,05$, sehingga dapat disimpulkan bahwa variable Tayangan Itaewon Class (X) berpengaruh positif terhadap variable Motivasi menjadi entrepreneurship (Y).

Tabel 12 Tabel Koefisien Determinasi

\begin{tabular}{lcccc}
\hline \multicolumn{4}{c}{ Model Summary } \\
\hline Model & $\mathrm{R}$ & $\mathrm{R}$ & $\begin{array}{c}\text { Adjusted R } \\
\text { Squar } \\
\text { Square }\end{array}$ & $\begin{array}{c}\text { Std. Error } \\
\text { of the } \\
\text { Estimate }\end{array}$ \\
\hline 1 & $.566^{\mathrm{a}}$ & .320 & .287 & 4.15834 \\
\hline
\end{tabular}


Dari tabel diatas diperolah nilai Adjusted $R^{2}=0,287=28,7 \%$. Ini berarti besarnya pengaruh intensitas, isi pesan, dan daya tarik berpengaruh terhadap Motivasi menjadi entrepreneurship sebesar 28,7\% dan sisanya dipengaruhi oleh variable lain yang tidak masuk dalam penelitian ini.

Tabel 13 Uji Parsial T

\begin{tabular}{|c|c|c|c|c|c|}
\hline \multicolumn{6}{|c|}{ Coefficients $^{\mathbf{a}}$} \\
\hline \multirow[b]{2}{*}{ Model } & \multicolumn{2}{|c|}{$\begin{array}{c}\text { Unstandardized } \\
\text { Coefficients }\end{array}$} & \multirow{2}{*}{$\begin{array}{c}\text { Standardized } \\
\text { Coefficients }\end{array}$} & \multirow[b]{2}{*}{$\mathrm{t}$} & \multirow[b]{2}{*}{ Sig. } \\
\hline & $\mathrm{B}$ & Std. Error & & & \\
\hline (Constant) & 1.235 & 1.217 & & 1.015 & .314 \\
\hline $\begin{array}{l}\text { INTENSIT } \\
\text { AS } \\
\end{array}$ & -.020 & .044 & -.016 & -.448 & .656 \\
\hline ISI PESAN & .137 & .062 & .089 & 2.213 & .031 \\
\hline $\begin{array}{l}\text { DAYA } \\
\text { TARIK }\end{array}$ & 1.393 & .059 & .919 & 23.740 & .000 \\
\hline
\end{tabular}

Hasil analisis regresi untuk variabel X1 Intensitas didapatkan nilai t hitung sebesar 0,448<1,999 dan nilai signifikan (Sig) 0,656>0,05. Maka dapat disimpulkan bahwa H0 diterima dan Ha ditolak, ini berarti intensitas tidak berpengaruh signifikan terhadap motivasi menjadi entrepreneurship (Y). Pada variabel (X2) Isi Pesan didapatkan nilai t hitung = 2,213>t tabel 1,999 dan nilai signifikan $(\mathrm{Sig})=0,031<0,05$ jadi H0 ditolak dan Ha diterima, yang artinya Isi Pesan berpengaruh signifikan terhadap motivasi menjadi entrepreneurship (Y). Pada variabel (X3) Daya Tarik didapatkan nilai t hitung $=23,740>1,999$ dan nilai signigikan $(\mathrm{Sig})=0,000<0,05$ jadi H0 ditolak dan Ha diterina, yang artinya Daya Tarik berpengaruh signifikan terhadap motivasi menjadi entrepreneurship (Y).

Drama Korea "Itaewon Class" dipilih karena tayangan tersebut di tahun 2020 cukup populer dengan tingkat rating yang cukup tinggi. Ada 80,61\% survei yang dilakukan oleh tim Tirto (2017) yaitu masyarakat penyuka drama Korea menyatakan alur cerita yang menarik dan tidak bertele - tele merupakan alasan utama mereka menonton drama Korea. Dengan begitu bisa terlihat bahwa drama Korea "Itaewon Class" cukup populer karena menarik perhatian masyarakat salah satunya Komunitas Pecinta Budaya Korea dengan alur cerita yang tidak biasa yaitu tentang usaha dalam berbisnis. Hal ini juga sudah dibuktikan dari hasil penelitian secara parsial dari ketiga variabel X1 Intensitas, X2 Isi Pesan, X3 Daya Tarik, hanya 
variabel X1 saja atau Intensitas yang tidak berpengaruh terhadap motivasi menjadi entrepreneurship sedangkan X2 Isi Pesan dan X3 Daya Tarik memiliki pengaruh signifikan terhadap motivasi menjadi entrepreneurship.

Fungsi penelitian ini adalah untuk mengetahui apakah tayangan drama Korea "Itaewon Class" dapat mempengaruhi Komunitas Pecinta Budaya Korea untuk menjadi entrepreneurship. Dari pengaruh yang di dapat pun membuat pengaruh yang positif bagi Komunitas Pecinta Budaya Korea bahwa ternyata melalui tayangan drama Korea yang memang mereka sukai dapat memberikan efek yang positif terhadap motivasi nya.

Hasil penelitian yang menunjukkan bahwa intensitas tayangan drama Korea Itaewon Class tidak berpengaruh signifikan terhadap motivasi menjadi entrepreneurship adalah sebesar (Sig) 0,656>0,05. Hal ini berkaitan dengan membicarakan intensitas menonton tayangan termasuk dalam peristiwa yang bisa diamati dalam teori uses and effect yang dikemukakan Bungin (2006), terjadi pada penggunaan media massa dengan jumlah responden 66 bahwa tidak dapat diharapkan semua sampel dapat ikut serta menonton tayangan lebih dari 1 kali penayangan drama Korea Itaewon Class namun Intensitas responden dalam menonton tayangan drama Korea Itaewon Class berbeda-beda, ada yang 5 kali penayangan, 3 kali penayangan bahkan responden cukup mendapatkan stimulus serta rangsangan untuk menonton tayangan Itaewon Class cukup dengan 1 kali penayangan.

Hasil penelitian yang menunjukkan bahwa isi pesan tayangan drama Korea Itaewon Class berpengaruh signifikan terhadap motivasi menjadi entrepreneurship adalah sebesar (Sig) 0,031<0,05. Hal ini menunjukkan bahwa teori uses and effect adalah pengetahuan mengenai penggunaan media. Dan penyebabnya adalah alur cerita dan moral value mengenai berbisnis dan mewujudkan keinginan menjadi entrepreneurship dalam tayangan Itaewon Class menghasilkan efek positif bagi responden dan manfaat tentang strategi berbisnis yang bisa dipelajari oleh responden dalam tayangan Itaewon Class. 


\section{SIMPULAN}

Hasil penelitian yang menujukkan bahwa daya tarik tayangan drama Korea Itaewon Class berpengaruh signifikan terhadap motivasi menjadi entrepreneurship adalah sebesar (Sig) $0,000<0,05$. Hal ini menunjukkan bahwa tayangan drama Korea Itaewon Class dapat menyuguhkan informasi dengan menarik yang menjadi daya tarik tersendiri dalam menyangkan peristiwa-peristiwa berbisnis dan bagaimana perjuangan seseorang dalam mewujudkan keinginannya. Tidak hanya didukung dengan alur cerita yang tidak membuat jenuh namun juga sinematografi negara Korea yang sudah banyak digandrungi oleh masyarakat Indonesia maupun Internasional.

Sehingga dapat disimpulkan bahwa responden mendapatkan hasil atau efek yang positif dari tayangan "Itaewon Class". Melalui tayangan tersebut, responden termotivasi untuk menjadi entrepreneurship dan berani untuk memulai usaha

\section{DAFTAR RUJUKAN}

Arikunto. (2010). Prosedur Penelitian: Suatu Pendekatan Praktek. Rineka Cipta. Bungin, B. (2006). Sosiologi Komunikasi. Kencana Prenada Media Grup.

Darmawan. (2013). Metode Penelitian Kuantitatif. Remaja Rosdakarya.

Dhani, A. (2017). Drama Korea Hidup Saya. Tirto.Id. https://tirto.id/drama-korea$\underline{\text { hidup-saya-cmbE }}$

Fitri, Diana Annisa. (2019). Pengaruh Drama Korea terhadap Karakter Mahasiswa PAI Universitas Islam Negeri Raden Intan Lampung. Skripsi. Uin Raden Intan Lampung

Nurudin. (2013). Pengantar Komunikasi Massa. PT. Raja Grafindo Persada.

Okirianti, K. E. (2011). Pengaruh Budaya Pop Korea terhadap Eksistensi Kebudayaan Asli Indonesia di Kalangan Remaja Kota Tegal. In Karya Ilmiah Remaja. Tegal.

Rahmawati, I. (2014). Pengaruh Tayangan Korean Wave di Internet terhadap Perilaku Komunitas Korean Beloved Addict (KBA). Universitas Islam Negeri Syarif Hidayatullah.

Shaleh, A. R. (2004). Psikologi Suatu Pengantar (Dalam Perspektif Islam). 
144 | Jurnal Pendidikan dan Kewirausahaan Vol. 9 No. 12021

Kencana.

Storey, J. (2010). Cultural Studies dan Kajian Budaya Pop. Jalasutra.

Sugiyono. (2010). Metode Penelitian Kuantitatif dan R\&D. Alfabeta.

Sunyoto, D. (2013). Kewirausahaan untuk Keesehatan. Nuha Medika.

Tirto. (2017). Drama Korea Hidup Saya. Tirto.Id. https://tirto.id/drama-koreahidup-saya-cmbE 